\title{
How Did Organizational Resilience Work Before and after the Financial Crisis? An Empirical Study
}

\author{
Pamela Palmi ${ }^{1}$, Domenico Morrone ${ }^{2}$, Pier Paolo Miglietta ${ }^{1} \&$ Giulio Fusco ${ }^{1}$ \\ ${ }^{1}$ Department of Economics and Management, University of Salento, Lecce, Italy \\ ${ }^{2}$ Department of Economics and Management, University LUM Jean Monnet, Casamassima (Ba), Italy \\ Correspondence: Domenico Morrone, Department of Economics and Management, University LUM Jean \\ Monnet, Casamassima (Ba), S.S. 100 Km 18, 70010, Italy. E-mail: morrone@lum.it
}

Received: July 28, 2018

doi:10.5539/ijbm.v13n10p54

\author{
Accepted: August 30, 2018 \\ Online Published: September 6, 2018 \\ URL: https://doi.org/10.5539/ijbm.v13n10p54
}

\begin{abstract}
The purpose of this paper is to assess the role of organizational resilience as an attitude, depending on the adoption of corporate governance, environmental and social practices (CESPs), in order to react to unexpected shocks, while preserving business sustainability. Organizational resilience is defined as the capacity for an enterprise to survive, to adapt and to grow in a turbulent change or unpredicted situation. Since organizational resilience is a latent path-dependent construct, it can be evaluated through long-term outcomes in an integrated perspective. The hypotheses are tested analyzing the economic performance of U.S. companies listed in Standard \& Poor's 500 index (S\&P 500) and their environmental, social and governance (ESG) data has been extracted from Asset4. The period in the study covers 14 years, from 2002 to 2015, collecting the seven years before and after the 2008 financial crisis. The results of the empirical analysis highlight that economic performances of listed companies are influenced, over the 14 year period considered in the study, not only by the traditional sustainable pillars (SEPs), but also by the corporate governance ones (CESPs).
\end{abstract}

Keywords: organizational resilience, corporate governance, environmental and social practices, financial crisis, sustainability

\section{Introduction}

In this study, we analyze the relationship between corporate governance, environmental and social practices (CESPs) and economic performance of companies, to evaluate their organizational resilience attitude, which helps to exploit opportunities and to mitigate threats. Organizational resilience, in fact, can be defined as the ability of organizations to anticipate, avoid, and adjust to shocks in their environment (Ortiz-de-Mandojana \& Bansal, 2016).

This concept cannot be addressed without the adoption of a sustainable and life cycle view since, considering for example operations management, the growing attention paid to natural resource conservation has led companies to integrate different and greener processes (Kleindorfer et al., 2005; Toma et al., 2016). Many authors have underlined how the management of resources, both tangible and intangible, natural and anthropic, have acquired an increased importance for all companies (Henriques, I., \& Sadorsky, P., 1999; Altieri et al., 2017), becoming a new field to acquire competitive advantages (Porter, M., \& Van der Linde, C., 1995). A sustainable perspective also needs to be involved in social practices. In the last few years the attention paid to working conditions has grown, involving developed and global sectors such as textiles (Graafland, 2002), as the attention paid to stakeholders (Garvare \& Johansson, 2010). Taking into account the research realized by Ortiz-de-Mandojana and Bansal (2016), the following analysis enlarges the adopted vision, adding to the social and environmental practices (SEPs) and the corporate governance concept. The introduction of this last element has been motivated by the consideration that a resilient approach cannot be definitive if not authorized and implemented by the most important management positions. Therefore corporate governance, considered in this work as the company's systems and procedures, has been included. The effects of the "shock", related to the worldwide financial and economic crisis of 2008, are considered as a concrete test to verify the effectiveness of an organizational resilient approach, based on CESPs, during a turbulent time that included all economic sectors where sustainable practices might have been more difficult to implement. 


\section{Literature Review}

The challenge for a sustainable development was officially launched forty years ago, as a consequence of different emergencies coming, above all, from the natural environment (Brundtland, 1987). The paradigm of sustainability was gradually enlarged and, in relation to the business context, all companies had to achieve economic results including environmental and social goals too (Elkington, 1997). As a consequence many scholars analyzed, through a business perspective, the contribution of environmental and social activities to increase, for example, their operations, reputation and market access (Wartick \& Cochran, 1985; Waddock \& Graves, 1997; Russo \& Fouts, 1997; Konar \& Cohen, 2001; Montabon et al., 2007; Calace et al., 2014; Morrone et al., 2015). The results showed that some factors produced immediate benefits, while the role of others still need to be deeply investigated (Griffin \& Mahon, 1997; Orlitzky et al., 2003; Jacobs et al., 2010). Different research was conducted to test the impact on business outcomes of responsible practices (Klassen \& McLaughlin, 1996; King \& Lenox, 2001; Horváthová, 2010). However, finding an analysis with a complete, integrated and long-term approach, where all the above-mentioned components are treated quantitatively, is not usual. There has certainly been some evidence produced along this path, but it is mostly limited to the short-term period (Stanwick and Stanwick, 1998). In addition, social and environmental practices (SEPs) cannot be considered without the corporate governance dimension, strictly connected with the latter (Johnson \& Greening, 1999). As noted by Walls et al. (2012), many attempts were made, coming for example from the OECD Principles, the UN Global Compact, the IFC (World Bank Group) or the International Corporate Governance Network, to demonstrate the influence of a company's environmental, social and governance responsibilities on its economic results and, at the same time, on its long-term sustainability performance (Blesener et al., 2009; Escudero et al., 2010; Mackenzie \& Hodgson, 2005; Tonello, 2010; White, 2006). Adopting a long-term perspective, in the framework of sustainable business practices, it is useful to explicitly consider another strategic element, organizational resilience, that is, a firm's ability to sense and correct maladaptive tendencies and cope positively with unexpected situations, as stated by Ortiz-de-Mandojana and Bansal (2016). They affirmed that firms that adopt responsible, social and environmental practices have lower financial volatility, higher sales growth and higher chances of survival, not finding any differences in the short-term profits. Resilience is the key factor to making firms able to move beyond survival and to prosper in complicated, uncertain and threatening environments (Lengnick-Hall et al., 2011), where the achievement of sustainability requires a systemic approach on a global level (Fiksel, 2006). The present study, founded on the long-term and short-term approaches and CESPs attributes, verifies the effectiveness of organizational resilience attitude to overcome economic and financial shocks.

\subsection{A Long-Term Perspective to Resilience}

In this work CESPs effects on long-term economic performances are analyzed to verify companies' organizational resilience attitude. Resilience is an ability that could refer to different environments. It is not strictly connected to a specific sector, since it characterizes the active growth of a structured modifiable organization that acts through temporal-space scales (Folke, 2006). The company that implements good CESPs, needs to test and to bring them to a long time perspective. It has to integrate good CESPs into its business culture, since the same practices can make the company more adaptive, more flexible and more shock resistant, in a word, more resilient. In fact, these practices are increasing more and more, according to the contingencies. They are varied and they fit in with corporate growth, not being a routine. Habitual behaviors are the first obstacle to flexibility in organizations (Gersick \& Hackman, 1990; Weiss \& Ilgen, 1985). Many times they could lead to failure, if there is not the ability to modify all previous settings to new contexts. CESPs could be a way to obtain malleable instruments to use in large and different circumstances. Since CESPs represent attributes of organizational resilience, it is clear that the latter cannot be intended as a fixed and pre-settled scheme. Following what is mentioned by different scholars (Gillet et al., 2006; Sutcliffe \& Vogus, 2003; Wildavsky, 1998), it is a sort of capability to modify negative and inflexible propensities to better face unpredicted events. The first research hypothesis comes from the foregoing consideration:

H.1. CESPs, as attributes of organizational resilience, influence the long-term performances of listed companies.

\subsection{CESPs Help Growth}

CESPs represent a virtuous direction to achieve organizational resilience, keeping market opportunities, as well as identifying new resources to develop. It is possible to reach these results following two processes.

When there is the necessity to re-project their own value proposition, companies that have resilient attributes can exploit, even creatively, concrete growth opportunities, aiming at a strategic improvement deriving mainly from the availability of relevant contextual information (Nicholls-Nixon, 2005). 
In the second case, a company can reach strategic objectives, increasing loyalty by inspired workers.

In the past, some analyses already affirmed that the companies that pay attention to social responsibility are more attractive to a quality workforce (Greening \& Turban, 2000; Turban \& Greening, 1997). CESPs are the way to better express a good working environment, as well as the most relevant values and rules in the organization (Turban \& Greening, 1997). In addition, CESPs can increase workers' inspiration, trust and sense of belonging (Branco \& Rodriguez, 2006). The human resources involved in a resilient company are more available to change when this change is necessary for development or for subsistence. This virtuous circle is the fundamental assumption to generate positive results, creating high quality and social-exchange relationships, as noted by Shin-Taylor and Seo (2012). It is widely recognized that well settled stakeholders' relations, involving suppliers and partners alike, are a concrete stimulus to creating new propositions, ensuring interesting opportunities. Then we support that:

H.2. There is a positive relationship between CESPs, intended as organizational resilience attributes, and economic performances, in particular companies that experience high-level CESPs have higher growth over the long term.

\subsection{CESPs have a Positive Effect on Financial Volatility}

Previous insights exposed how low resilience is connected with volatility, both on returns and on the markets. Hamal and Valikangas (2003) affirmed that a resilient approach is the key factor for a company that aims at shaping itself to the surrounding environment, foreseeing changes. In this way it is possible to reach the firm's objective of "zero trauma". In the following empirical analysis it is demonstrated that CESPs decrease financial volatility for two main reasons.

The first reason is related to the ability, for those companies that adopted CESPs, of quickly adjusting negative behaviors. When an organization is able to prevent future troubles, it is less exposed to the relative consequences (Garcia-Castro et al., 2010).

The second reason consists, always considering the presence of CESPs, in the possibility to create the proper conditions to avoid all extraordinary events that could impact negatively on companies' economic performances.

Bansal and Clelland (2004) expressed how the presence of high social and environmental practices in a firm's context is a concrete insurance against social and environmental risks. Moreover, this presence improves organizational legitimacy, reducing scrutiny and unsystematic market risk too. Therefore resilient organizations have the ability to sense dangerous situations, facing them, and they are also able to better manage risks (Donaldson, 1999; Ortitzky \& Benjamin, 2001). Previous studies put in relation social and environmental practices to financial risks, in the short term (Bansal \& Clelland, 2004; Godfrey, 2005; Orlizky \& Benjamin, 2001), but also in longer periods (Ortiz-De-Mandojana \& Bansal, 2016), in which companies are able, to anticipate, to learn and to adapt. In association with high CESPs, firms reached more stability, since they were able to overcome the risks, avoiding the ones that could affect the financial results. Starting from this observation, the empirical analysis aims at testing the third hypothesis:

H.3. Companies experiencing CESPS reduce financial volatility in the short-term period, around a financial crisis shock.

\section{Empirical Analysis}

\subsection{Data Collection}

The following analysis is related to 247 U.S. big companies listed in Standard \& Poor's 500 index, for which data about corporate governance scores, social scores, environmental scores, market value and net sales for the period 2002-2015 are available. The source for environmental, social and governance information (ESG) is ASSET4, the world's leading source of ESG data, providing professional investors with a new generation of investment research information and corporate executives ESG management and benchmarking capabilities. In particular, taking into account the official descriptions, the Social Score variable defines a firm's ability to create trust and loyalty with its human resources, clients and the society, adopting high value management practices. It is strictly connected with a firm's reputation and the health of its license to operate. The latter could be considered essential elements in producing long-term shareholder value. The Corporate Governance Score is an indicator to evaluate a company's systems and procedures, to observe if the managerial process is oriented to the best benefits of its long-term shareholders. This value produced indicates if a company is able to manage and verify its rights and responsibilities adopting, for example, incentives, checks and/or balances in the perspective of long-term shareholder value. The Environmental Score is related to the impact of a firm's action on the natural environment considering land, water, air or entire ecosystems. This variable is a clear indication of the attention 
paid to environmental risks/opportunities, to be considered in a long-term shareholder value framework. Finally, there are two other variables, the Market Value and Net Sales. The Market Value is the total market value of the company. Net Sales reports a company's revenue. For the latter two the measurement unit adopted is million dollars. In Table 1 the summary statistics have been illustrated.

Table 1. Descriptive statistics

\begin{tabular}{|c|c|c|c|c|c|}
\hline $\begin{array}{l}\text { Number } \\
\text { companies }\end{array}$ & Variables & Mean & Standard deviation & Minimum & Maximum \\
\hline \multirow{5}{*}{247} & Corporate Governance Score & 79.22 & 14.32 & 6.88 & 97.90 \\
\hline & Social Score & 58.30 & 31.55 & 8.28 & 97.47 \\
\hline & Environmental Score & 60.90 & 27.77 & 3.54 & 98.93 \\
\hline & Market Value & 34,030 & 51,698 & 502.42 & 484,133 \\
\hline & Net Sales & $24,650,961$ & $43,104,853$ & 40,422 & $485,651,000$ \\
\hline
\end{tabular}

\subsection{Models Tested}

The empirical analysis, extending the Ortiz-de-Mandojana and Bansal (2016) study, adds to the social and environmental scores, the corporate governance score as a further explanatory variable and considers a more recent time period.

The models are estimated for the 247 International listed companies in which reliable data exist for the Corporate Governance Score, Environmental Score, Social Score, Market Value and Net Sales. We analyzed the panel data for the period from 2002 to 2015.

Panel data analysis is a statistical method used in econometrics to analyze two-dimensional panel data. We have conducted different analyses to verify the robustness of empirical results.

The first model has the Market value as the dependent variable, while the second model has Net Sales as dependent variable. The dependent variable in each model has been regressed on independent variables, i.e. the ESG disclosure score sub-components (Corporate Governance score, Social Score and Environmental Score).

$$
\begin{aligned}
& \text { Ln Market Value } \\
& =\alpha_{1}+\beta_{1} \text { Ln Corporate Governance Score }{ }_{i, t}+\beta_{2} \text { Ln Social Score }_{i, t} \\
& +\beta_{3} \text { Ln Environmental Score }{ }_{i, t}+\alpha_{i}+u_{i, t} \\
& \text { Ln Net Sales }=\alpha_{1}+\beta_{1} \text { Ln Corporate Governance Score }_{i, t}+\beta_{2} \text { Ln Social Score }_{i, t} \\
& +\beta_{3} \text { Ln Environmental Score }{ }_{i, t}+\alpha_{i}+u_{i, t}
\end{aligned}
$$

In order to test Hypothesis 3 , we conducted the same empirical analyses, based on the above-mentioned models, distinguishing pre-crisis (2002-2007) and post crisis (2008-2015) periods.

\subsection{Results}

Results of our models show the effect of the independent variables on the dependent variables considered in this study. Tables 2 and 3 report, in particular, the coefficients of each variable obtained holding all the other variables constant, the standard errors (indicated in parentheses under the coefficients), the $p$-values (indicated with $(*),(* *)$ or $(* * *)$ on the basis of the statistical significance equal respectively to $10 \%, 5 \%, 1 \%)$ and summary statistics.

The columns labeled (1) and (2), included in Table 2, represent the results of fixed effect panel model analysis and help in testing Hypotheses 1 and 2.

Regression results (1) consider a linear relation between the dependent variable Ln Market Value and the independent variables. Regression results (2) consider instead a linear relation between the dependent variable Ln Net Sales and the independent variables.

Results of the first panel analysis show that all variables taken into consideration are significant, highlighting $p$-values $<0.001$.

The Corporate Governance score has a positive relation with our dependent variable. In fact, when independent variables increase by $1 \%$, Market value records an increase of almost $0.20 \%$. It is possible to identify the same 
positive relation also with the other independent variables. In particular, an increase of $1 \%$ in the Social Score implies an increase of almost $0.22 \%$, and when the Environmental score increases by $1 \%$ the dependent variable Market value increases by $0.12 \%$. The adjusted $\mathrm{R}^{2}$ of regression (1) assumes a value equal to 0.85 , quantifying the extent to which the explanatory variables explain the variation in the dependent variable.

In the Model (2) the dependent variable is Net Sales. Results demonstrate the same positive relation described in the regression (1) between dependent variable and the above-mentioned independent variables. These results confirm the robustness of the analysis, since the impact produced on both economic dependent variables is similar.

Table 2. Fixed effect regression results for the whole panel data

\begin{tabular}{lll}
\hline Regressor & Ln Market Value (1) & Ln Net Sales (2) \\
\hline Ln Corporate Governance Score & $0.1951^{* * *}$ & $0.1121^{* * *}$ \\
& $(0.0578)$ & $(0.0562)$ \\
Ln Social Score & $0.2154^{* * *}$ & $0.1737^{* * *}$ \\
Ln Environmental Score & $(0.0360)$ & $(0.2997)$ \\
& $0.1245^{* * *}$ & $0.1838^{* *}$ \\
Constant & $(0.0293)$ & $(0.0270)$ \\
Summary Statistics & $7.5704^{* * *}$ & $14.3850^{* * *}$ \\
SER & $(0.2405)$ & $(0.2577)$ \\
Adjusted $R^{2}$ & & \\
\hline
\end{tabular}

In order to test the research Hypothesis 3, we conducted another empirical analysis aimed at assessing pre-crisis (2002-2007) and post crisis (2008-2015) short-term effects on dependent variables.

Table 3. Fixed effect regression results for the pre-crisis and post-crisis panels

\begin{tabular}{|c|c|c|c|c|}
\hline Regressor & $\begin{array}{c}\text { Ln Market Value } \\
\text { (3) }\end{array}$ & $\begin{array}{c}\text { Ln Net Sales } \\
(4)\end{array}$ & $\begin{array}{c}\text { Ln Market Value } \\
(5)\end{array}$ & $\begin{array}{c}\text { Ln Net Sales } \\
(6)\end{array}$ \\
\hline Ln Corporate Governance & $0.1210 * *$ & $0.1244 * * *$ & $0.3651 * *$ & 0.0481 \\
\hline Score & $(0.0481)$ & $(0.0371)$ & $(0.1631)$ & $(0.1343)$ \\
\hline Ln Social Score & $\begin{array}{c}0.2298 * * * \\
(0.0328)\end{array}$ & $\begin{array}{c}0.1547 * * * \\
(0.0225)\end{array}$ & $\begin{array}{l}0.0205 \\
(0.1012)\end{array}$ & $\begin{array}{c}0.0489 \\
(0.0998)\end{array}$ \\
\hline Ln Environmental Score & $\begin{array}{c}0.1015 * * * \\
(0.0328)\end{array}$ & $\begin{array}{c}0.1163 * * * \\
(0.0263)\end{array}$ & $\begin{array}{c}0.3203 * * * \\
(0.0623)\end{array}$ & $\begin{array}{c}0.2651 * * * \\
(0.0645)\end{array}$ \\
\hline Constant & $\begin{array}{c}7.8696 * * * \\
(0.0193)\end{array}$ & $\begin{array}{c}14.5490 * * * \\
(0.1510)\end{array}$ & $\begin{array}{c}6.8649 * * * \\
(0.8275)\end{array}$ & $\begin{array}{c}14.9199 * * * \\
(0.8084)\end{array}$ \\
\hline $\begin{array}{l}\text { Summary Statistics } \\
\text { SER } \\
\text { Adjusted } R^{2}\end{array}$ & $\begin{array}{l}0.3799 \\
0.9094\end{array}$ & $\begin{array}{l}0.2483 \\
0.9640 \\
\end{array}$ & $\begin{array}{l}0.5526 \\
0.7794 \\
\end{array}$ & $\begin{array}{l}0.4803 \\
0.8527 \\
\end{array}$ \\
\hline
\end{tabular}

Columns labeled (3), (4), (5) and (6), included in Table 3, show the results of fixed effect panel model analysis describing the effect of independent variables on the economic dependent variables, i.e. Market Value and Net Sales, respectively in the pre-crisis and in the post-crisis periods.

In the pre-crisis period each independent variable is significant and affects the selected dependent variables of our analysis as for the analysis that considered the whole panel data, registering just some variations in the coefficient values.

In the post-crisis period results highlight some different effects. In particular the Social Score variable appears to be insignificant in determining variations on Market Value and Net Sales. The same effect is registered for the Corporate Governance Score variable in the regression (6), attaining influence on Net Sales.

The only variable that confirms a positive and significant effect on the dependent variable in the post-crisis period is the Environmental Score variable. An increase of $1 \%$ in the score implies a correspondent increase in Market Value and Net Sales respectively of $0.32 \%$ and $0.26 \%$, even more relevant than in the pre-crisis period. 


\section{Conclusion and Discussion}

The present paper investigates the relationship between governance, environmental and social practices (CESPs) and economic performances, to test companies' organizational resilience, making use of proxies, individuated by the Bloomberg ESG disclosure scores.

Results of empirical analysis underline the importance of organizational resilience, intended as the ability of companies to change their corporate structure facing shocks. As demonstrated by the regression results (1) and (2), CESPs affect positively the economic performance of businesses in the long-term, confirming Hypotheses 1 and 2, highlighting consequently an organizational resilience attitude.

Listed companies, in fact, over the 14year long-term period considered in the study, experience a strong influence of the organizational resilience driving factors, consisting not only in the traditional sustainable pillars (SEPs), but also in the corporate governance ones (CESPs). In particular, increases in the above-mentioned scores have implied a better market positioning, proved by an increase in their market value and net sales, i.e. in their ability to adjust themselves to the context and in their sustainability.

Moreover, our analysis contributes to evaluating listed company behaviors before and after the shock caused by the financial crisis in 2008, testing Hypothesis 3.

The organizational resilient approach appears to be effective in the pre-crisis (short-term) period, but not completely in the (short-term) post-crisis period. In particularly turbulent times, which concern all economic sectors, sustainable practices could be more difficult to implement. In this context the pillar, which confirms its effectiveness in strengthening business sustainability and economic performance in general, reducing financial volatility, is the environmental one.

Figure 1 illustrated below provides a matrix conceptual framework, which allows for the identification of the company level of organizational resilience.

\begin{tabular}{|c|c|c|c|}
\hline & Short-term pre-crisis & Short-term post-crisis & Level of resilience \\
\hline Environmental score & Market Value & Market Value & $\begin{array}{c}\text { HIGH } \\
\text { (RESILIENT) }\end{array}$ \\
\hline Corporate Governance score & Market Value & Market Value & $\begin{array}{c}\text { MEDIUM } \\
\text { (ADAPTIVE) }\end{array}$ \\
\hline Social score & & Market & $\begin{array}{c}\text { LOW } \\
\text { (SURVIVING) }\end{array}$ \\
\hline
\end{tabular}

Figure 1. Organizational resilience matrix based on empirical results

As we can see from Figure 1, the maximum level of resilience is certainly ensured by a green approach. The environmental practices (EPs), which capture green attitude in the business activity, affect market value and profitability (net sales) both in a short-term pre- and post-crisis perspective. Managerial efforts should be therefore addressed at increasing this environmental score, through green policies, in order to aim business survival at attaining a high resilience level. This theoretical result, which has been developed through the empirical analysis, is also in line with the broad scientific literature in this research field (Chen et al., 2018; Montabon et al, 2007). The latter shows that green initiatives, especially those green practices aimed at improving environmental protection such as carbon and waste reduction, have a positive indirect impact on financial performance.

Analyzing the corporate governance score, Figure 1 highlights that institutional policies and, in particular, responsibility and control processes, ensure market value and net sales increases in the short-term pre-crisis, but only market value increases and there is no impact on profitability in the post-crisis, determining a sort of business adaptive approach to crisis.

Turning the focus on the social sub-component of the ESG score, the proxy of business social practices (SPs), the conceptual matrix highlights insignificant effects after the 2008 crisis. SPs ensure good economic performance in the pre-crisis. This does not mean that SPs imply negative economic performance in the post-crisis, but surely they could not confirm a positive contribution to market value and profitability. This could be defined as a business surviving attitude, different from a plenty resilience approach. 
Firms with high CESPs experience less financial volatility over the long-term, overcoming more effectively the financial crises shock, even with some differences in the drivers (Nollet et al., 2016).

For this reason the management should monitor business organizational resilience approaches and use information deriving from them, in order to choose the most relevant key factors to overcome shocks. As already highlighted in some ecological literature (Toma et al., 2017), the environmental dimension plays a fundamental role, showing that firms which offer environmental and ecosystem services are highly resilient.

\section{References}

Altieri, G. Morrone, D., \& Russo, A. (2017). Sustainability knowledge as driver of firm performance: evidence from supply chain management practices. In (Eds.), Proceedings of the $7^{\text {th }}$ International Symposium on Natural Resources Management. Zajecar, Serbia: John Naisbitt University.

Bansal, P., \& Clelland, I. (2004). Talking trash: Legitimacy, impression management, and unsystematic risk in the context of the natural environment. Academy of Management Journal, 47(1), 93-103. https://doi.org/10.5465/20159562

Blesener, S., Cruz-Osorio, J., Gardiner, L., \& Germanova, R. (2009). Stakeholder engagement and the board: Integrating best governance practices. In Washington, DC: The Global Corporate Governance Forum.

Branco, M. C., \& Rodrigues, L. L. (2006). Corporate social responsibility and resource-based perspectives. Journal of business Ethics, 69(2), 111-132. https://doi.org/10.1007/s10551-006-9071-z

Brundtland, G. H. (1987). Report of the World Commission on environment and development:" our common future". United Nations.

Calace, D., Morrone, D., \& Russo, A. (2014). Corporate sustainability, green marketing and reporting: where are we going?. Analele Universității din Oradea, Fascicula: Protecția Mediului, 23, 59-68.

Chen, F., Ngniatedema, T., \& Li, S. (2018). A cross-country comparison of green initiatives, green performance and financial performance. Management Decision. https://doi.org/10.1108/MD-08-2017-0761

Donaldson, L. (1999). Performance-driven Organizational Change: The Organzational Portfolio, Sage: Thousand Oaks, CA.

Elkington, J. (1997). Cannibals with forks. The triple bottom line of 21st century, 73.

Escudero, M., Power, G., Waddock, S. A., Beamish, P., \& Cruse, S. (2010). Moving upwards: the involvement of boards of directors in the UN Global Compact. New York, NY: United Nations Global Compact Lead.

Fiksel, J. (2006). Sustainability and resilience: toward a systems approach. Sustainability: Science, Practice, \& Policy, 2(2). https://doi.org/10.1080/15487733.2006.11907980

Folke, C. (2006). Resilience: The emergence of a perspective for social-ecological systems analyses. Global Environmental Change, 16(3), 253-267. https://doi.org/10.1016/j.gloenvcha.2006.04.002

Garcia-Castro, R., Ariño, M. A., \& Canela, M. A. (2010). Does social performance really lead to financial performance? Accounting for endogeneity. Journal of Business Ethics, 92(1), 107-126. https://doi.org/10.1007/s10551-009-0143-8

Garvare, R., \& Johansson, P. (2010). Management for sustainability-a stakeholder theory. Total quality management, 21(7), 737-744. https://doi.org/10.1080/14783363.2010.483095

Gersick, C. J., \& Hackman, J. R. (1990). Habitual routines in task-performing groups. Organizational Behavior and Human Decision Processes, 47(1), 65-97.

Gittell, J. H., Cameron, K., Lim, S., \& Rivas, V. (2006). Relationships, layoffs, and organizational resilience: Airline industry responses to September 11. The Journal of Applied Behavioral Science, 42(3), 300-329. https://doi.org/10.1177/0021886306286466

Godfrey, P. C. (2005). The relationship between corporate philanthropy and shareholder wealth: A risk management perspective. Academy of Management Review, 30(4), 777-798. https://doi.org/10.5465/amr.2005.18378878

Graafland, J. J. (2002). Sourcing ethics in the textile sector: the case of C\&A. Business Ethics: A European Review, 11(3), 282-294. https://doi.org/10.1111/1467-8608.00286

Greening, D. W., \& Turban, D. B. (2000). Corporate social performance as a competitive advantage in attracting a quality workforce. Business \& Society, 39(3), 254-280. https://doi.org/10.1177/000765030003900302 
Griffin, J. J., \& Mahon, J. F. (1997). The corporate social performance and corporate financial performance debate: Twenty-five years of incomparable research. Business \& society, 36(1), 5-31. https://doi.org/10.1177/000765039703600102

Hamel, G., \& Valikangas, L. (2003). Why resilience matters. Harvard Business Review, 81(9), 56-57.

Henriques, I., \& Sadorsky, P. (1999). The relationship between environmental commitment and managerial perceptions of stakeholder importance. Academy of management Journal, 42(1), 87-99. https://doi.org/10.5465/256876

Horváthová, E. (2010). Does environmental performance affect financial performance? A meta-analysis. Ecological Economics, 70(1), 52-59. https://doi.org/10.1016/j.ecolecon.2010.04.004

Jacobs, B. W., Singhal, V. R., \& Subramanian, R. (2010). An empirical investigation of environmental performance and the market value of the firm. Journal of Operations Management, 28(5), 430-441. https://doi.org/10.1016/j.jom.2010.01.001

Johnson, R. A., \& Greening, D. W. (1999). The effects of corporate governance and institutional ownership types on corporate social performance. Academy of Management Journal, 42(5), 564-576. https://doi.org/10.5465/256977

King, A. A., \& Lenox, M. J. (2001). Does it really pay to be green? An empirical study of firm environmental and financial performance: An empirical study of firm environmental and financial performance. Journal of Industrial Ecology, 5(1), 105-116. https://doi.org/10.1162/108819801753358526

Klassen, R. D., \& McLaughlin, C. P. (1996). The impact of environmental management on firm performance. Management science, 42(8), 1199-1214. https://doi.org/10.1287/mnsc.42.8.1199

Kleindorfer, P. R., Singhal, K., \& Van Wassenhove, L. N. (2005). Sustainable operations management. $\begin{array}{llll}\text { Production and } \quad \text { Operations } & \text { Management, }\end{array}$ https://doi.org/10.1111/j.1937-5956.2005.tb00235.x

Konar, S., \& Cohen, M. A. (2001). Does the market value environmental performance?. The review of Economics and Statistics, 83(2), 281-289. https://doi.org/10.1162/00346530151143815

Lengnick-Hall, C. A., Beck, T. E., \& Lengnick-Hall, M. L. (2011). Developing a capacity for organizational resilience through strategic human resource management. Human Resource Management Review, 21(3), 243-255. https://doi.org/10.1016/j.hrmr.2010.07.001

Linnenluecke M. K. (2017). Resilience in Business and Management Research: A Review of Influential Publications and a Research Agenda, International Journal of Management Reviews, 19, 4-30. https://doi.org/10.1111/ijmr.12076

Mackenzie, C., \& Hogdson, S. (2005). Rewarding Virtue: Effective Board Action on Corporate Responsibility, Full report, Insight Investment, Business in the Community and the FTSE Group. Published by Business in the Community, 137.

Montabon, F., Sroufe, R., \& Narasimhan, R. (2007). An examination of corporate reporting, environmental management practices and firm performance. Journal of Operations Management, 25(5), 998-1014. https://doi.org/10.1016/j.jom.2006.10.003

Morrone, D., Russo, A., \& Calace, D. (2015). The Effectiveness of Green Marketing Strategies in the Automotive Industry: A Consumer-Based Analysis. Journal of Marketing Development and Competitiveness, 9(2), 59-71.

Nicholls-Nixon, C. L. (2005). Rapid growth and high performance: The entrepreneur's “impossible dream?". The Academy of Management Executive, 19(1), 77-89. https://doi.org/10.5465/ame.2005.15841955

Nollet, J., Filis, G., \& Mitrokostas, E. (2016). Corporate social responsibility and financial performance: A non-linear and disaggregated approach. Economic Modelling, 52, 400-407. https://doi.org/10.1016/j.econmod.2015.09.019

Orlitzky, M., \& Benjamin, J. D. (2001). Corporate social performance and firm risk: A meta-analytic review. Business \& Society, 40(4), 369-396. https://doi.org/10.1177/000765030104000402

Orlitzky, M., Schmidt, F. L., \& Rynes, S. L. (2003). Corporate social and financial performance: A meta-analysis. Organization studies, 24(3), 403-441. https://doi.org/10.1177/0170840603024003910

Ortiz-de-Mandojana, N., \& Bansal, P. (2016). The long-term benefits of organizational resilience through 
sustainable business practices. Strategic Management Journal, 37(8), 1615-1631. https://doi.org/10.1002/smj.2410

Porter, M., \& Van der Linde, C. (1995). Green and competitive: ending the stalemate. The Dynamics of the Eco-Efficient Economy: Environmental Regulation and Competitive Advantage, 33.

Russo, M. V., \& Fouts, P. A. (1997). A resource-based perspective on corporate environmental performance and profitability. Academy of management Journal, 40(3), 534-559. https://doi.org/10.5465/257052

Shin, J., Taylor, M. S., \& Seo, M. (2012). Resources for organizational change: The effects of individual resilience and the nature of the employment relationship on employees' reactions to change. Academy of Management Journal, 55, 727-748. https://doi.org/10.5465/amj.2010.0325

Stanwick, P. A., \& Stanwick, S. D. (1998). The relationship between corporate social performance, and organizational size, financial performance, and environmental performance: An empirical examination. Journal of business ethics, 17(2), 195-204. https://doi.org/10.1023/A:1005784421547

Slawinski, N., \& Bansal P. (2015). Short on time: intertemporal tensions in business sustainability. Organization Science, 26(2), 531-549. https://doi.org/10.1287/orsc.2014.0960

Sutcliffe, K. M., \& Vogus T. J. (2003). Organizing for resilence. In Cameron, K. S., Dutton, J. E., Quinn, R. E. (Eds), Positive Organizational Scholarship: Foundations of a New Discipline. Berret-Koehler: San Francisco, CA: 94-110.

Toma, P., Miglietta, P. P., Zurlini, G., Valente, D., \& Petrosillo, I. (2017). A non-parametric bootstrap-data envelopment analysis approach for environmental policy planning and management of agricultural efficiency in EU countries. Ecological Indicators, 83, 132-143.

Toma, P., Massari, S., \& Miglietta, P. P. (2016). Natural resource use efficiency and economic productivity. In Massari, S., Sonnemann, G., Balkau, F. (Eds), Life Cycle Approaches to Sustainable Regional Development (pp. 143-148).

Tonello, M. (2010). Sustainability in the boardroom: The role of the board in sustainability oversight. In The Conference Board.

Turban, D. B., \& Greening, D. W. (1997). Corporate social performance and organizational attractiveness to prospective employees. Academy of management journal, 40(3), 658-672. https://doi.org/10.5465/257057

Waddock, S. A., \& Graves, S. B. (1997). The corporate social performance-financial performance link. Strategic Management Journal, 303-319. https://doi.org/10.1002/(SICI)1097-0266(199704)18:4<303::AID-SMJ869>3.0.CO;2-G

Walls, J. L., Berrone, P., \& Phan, P. H. (2012). Corporate governance and environmental performance: Is there really a link? Strategic Management Journal, 33(8), 885-913. https://doi.org/10.1002/smj.1952

Wartick, S. L., \& Cochran, P. L. (1985). The evolution of the corporate social performance model. Academy of management review, 10(4), 758-769. https://doi.org/10.5465/amr.1985.4279099

Weiss, H. M., \& Ilgen, D. R. (1985). Routinized behavior in organizations. Journal of Behavioral Economics, 14(1), 57-67. https://doi.org/10.1016/0090-5720(85)90005-1

White, A. L. (2006). The stakeholder fiduciary: CSR, governance and the future of boards. Business for Social Responsibility, 1-17.

Wildavsky, A. (1988). Searching for Safety. Transaction Books: New Brunswick, NJ.

\section{Copyrights}

Copyright for this article is retained by the author(s), with first publication rights granted to the journal.

This is an open-access article distributed under the terms and conditions of the Creative Commons Attribution license (http://creativecommons.org/licenses/by/4.0/). 